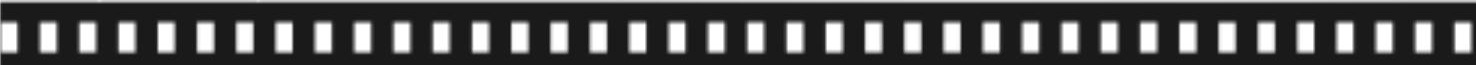

\author{
A trajetória imagética de Lula: de \\ líder sindical a presidente da República

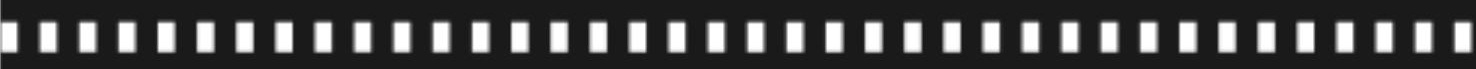

Cristiane Sabino Silva

Paulo César Boni 


\title{
A trajetória imagética de Lula: de líder sindical a presidente da República
} Lula's imagetic path: from union leader to president of the Republic

Cristiane Sabino Silva*

Paulo César Boni**

\begin{abstract}
Resumo: Este trabalho estuda as mudanças na imagem de Luiz Inácio Lula da Silva, da época em que era presidente do Sindicato dos Metalúrgicos do ABC, em 1979, até sua última campanha presidencial, em 2002. O estudo limita-se às fotografias publicadas pela revista Veja, veículo escolhido como objeto de estudo. Partindo do pressuposto que a revista é uma grande formadora de opinião, o estudo observa se há alguma relação-ou influência-entre o tratamento imagético dispensado à Lula e seu desempenho nas disputas eleitorais para a Presidência da República de que participou, ou seja, as de 1989, 1994, 1998 e 2002.
\end{abstract}

Palavras-chave: Lula; imagem; mídia; eleições.

\begin{abstract}
This work studies the changes in image undergone by Luiz Inácio Lula da Silva, from the time he was the $\mathrm{ABC}$ metallurgical workers union president in 1979, to his last presidential campaign, in 2002. The study will be limited to photographs published by Veja magazine, as a source chosen for analysis. Starting from the presupposition that this magazine is highly influential on public opinion, the study tries to find whether or not there has been any correlation - or influence - between the imagetic treatment given to Lula, and his actual performance on the polls for the Presidency of the Republic: those of 1989, 1994, 1998 and 2002.
\end{abstract}

Key-words: Lula; image; media; elections.

\footnotetext{
*Graduada em Comunicação Social - Habilitação em Jornalismo pela Universidade Estadual de Londrina.

**Doutor em Ciências da Comunicação pela ECA/USP. Coordenador do Curso de Especialização em Fotografia da Universidade Estadual de Londrina.
} 


\section{Introdução}

O presidente Luiz Inácio Lula da Silva é, hoje, uma das personalidades nacionais mais conhecidas. Mas foi em 1979, como presidente do Sindicato dos Metalúrgicos do ABC, em São Paulo, lutando por melhores condições de trabalho, que, pela primeira vez, ganhou as páginas dos jornais e revistas e foi notícia em todo o mundo. Desde então, fundou o Partido dos Trabalhadores (PT) e se lançou candidato à Presidência da República em quatro eleições seguidas, sendo eleito apenas na última, em 2002. Durante esse período, seu comportamento e imagem foram mudando gradativamente, baseado em experiências vividas e acompanhando as exigências de cada pleito.

As mudanças na imagem de Lula podem ser observadas, ao longo dos anos, em todos os veículos impressos nacionais. Para este artigo, o veículo selecionado foi a revista Veja. Foram selecionados os anos de 1979, 1989, 1994, 1998 e 2002, especificamente, por terem sido os anos de maior destaque de Lula. Em 1979, ele foi eleito presidente do sindicato dos metalúrgicos, liderou uma greve unificada da classe e, principalmente em razão da greve, tornou-se uma liderança conhecida nacionalmente. Nos demais anos, ganhou destaque na mídia por ter sido candidato à Presidência da República.

A análise das imagens foi feita pelo processo de desconstrução, com aplicações conceituais inerentes aos elementos da linguagem fotográfica. Por meio desses elementos, pode-se inferir as intenções de comunicação de quem produziu as fotografias. As escolhas do fotógrafo, quase sempre, manifestam suas opiniões e as da empresa para a qual trabalha. Esses elementos, se bem trabalhados, são capazes de "provocar" diversas leituras de uma mesma realidade. É o que se pode chamar de "manipulação" da realidade, procedimento que, desde a invenção da fotografia, tem gerado acalorados debates éticos, como bem observa Gisèle Freund (1995): “A utilização da imagem fotográfica torna-se um problema ético a partir do momento em que podemos deliberadamente servir-nos dela para falsificar os fatos." 
As imagens não foram analisadas de forma descontextualizada. Levou-se em consideração o teor da reportagem e o momento político em que se inseria, de modo a oferecer um amplo panorama imagético da trajetória do referido político.

Este trabalho analisou a trajetória de Lula por 23 anos. Ao longo desse tempo, mudanças significativas foram percebidas em sua imagem.

\section{9 - Nasce um líder nacional}

Em 1979, aparentemente, Lula ainda não tinha pretensões políticas, era apenas um líder metalúrgico. E porque era este o seu mundo, bem se adequava a ele na maneira de se comportar, de se vestir, de falar. Para os "companheiros", ele os representava bem, não importando se falasse certo ou não; exprimia o desejo da classe.

Nas primeiras edições do ano, entre janeiro e fevereiro, a revista mostrava Lula circunscrito ao seu mundo, o do Sindicato dos Metalúrgicos. Ele ainda não era chamado de líder, mas se destacava entre os pares. Nas fotos, aparecia em salas de reuniões, junto a outros trabalhadores, expondo suas idéias e apreendendo a atenção de todos. As roupas denunciavam sua semelhança com os demais: camisetas de algodão ou camisas abertas, com as mangas arregaçadas.

Em 28 de março, Lula foi capa da Veja. Foi sua única capa e única foto colorida no ano. Em plano americano, o sindicalista era escoltado por policiais após ser decretada a intervenção no sindicato em função da greve. Estava cabisbaixo, tinha o olhar fixo e expressão contida. A imagem parece cortada pelo que Martine Joly (1996) chama de moldura.

A estratégia de confundir o quadro (ou os limites) da imagem e a borda do suporte tem consequiências particulares sobre o imaginário do espectador. Esse corte, atribuído mais à dimensão do suporte do que a uma escolha de enquadramento, leva o espectador a constituir imaginariamente o que não se vê no campo visual da representação, mas que o completa: ofora de campo. (JOLY, 1996, p.94). 


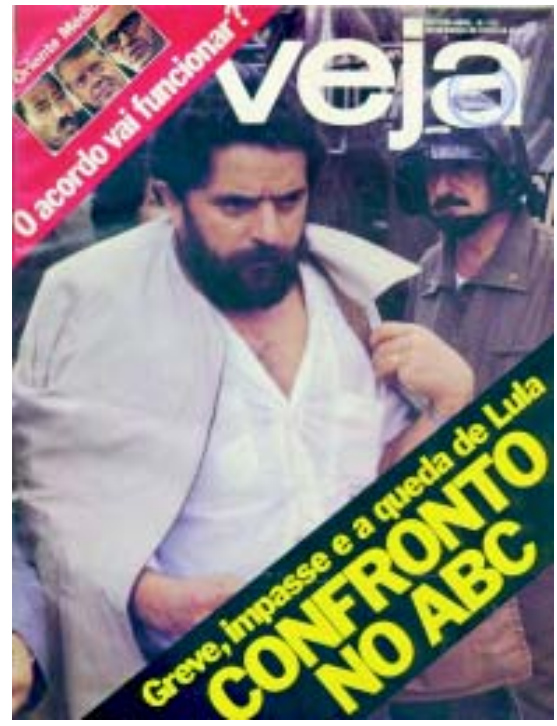

Foto: Pedro Martinelli - Revista Veja, n.551, 28 de março de 1979, capa

As próprias manchetes da capa da revista constituíram uma moldura na fotografia e contribuíram para confundir seu significado. Assim como observa Martine Joly (1996), o espectador constitui imaginariamente o que não vê e pode chegar a concluir que o líder estava sendo preso. A chamada da matéria Greve, impasse e a queda de Lula - CONFRONTO NO ABC, em amarelo com fundo preto, parecia com uma faixa de censura à própria foto.

A opção do fotógrafo por incluir na imagem um policial ao lado de Lula reforçou no leitor a hipótese da detenção do sindicalista. Ainda vigorava, neste ano, a ditadura militar, e a repressão aos movimentos contrários aos interesses do governo era feita com veemência pelo aparato policial. A presença - e patrulha - policial era intensa na sociedade. O Estado utilizava-se de todos os meios necessários para manter a ordem. A expressão de Lula revelava, neste momento, retidão e obediência. Não acatar a intervenção poderia resultar na ação violenta da polícia, com o uso da força. 


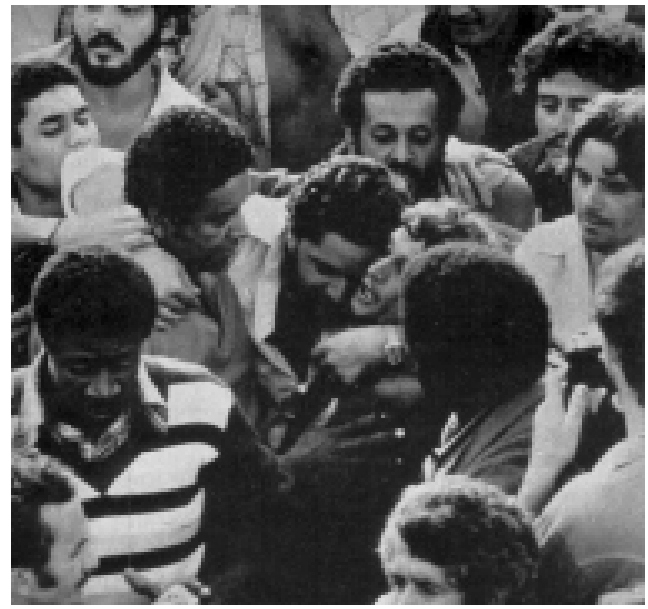

Foto: Irmo Celso - Revista Veja, n.552,

4 de abril de 1979, p.26

Em quatro de abril, a matéria Como a greve acabou mostrou Lula mais animado. Na imagem em plongée, ele é abraçado pelos "companheiros", agradecidos por mais uma conquista. A foto, apesar de um recorte bem limitado, trazia a impressão de que uma multidão o acompanhava, e não apenas aqueles que na foto o saúdam. Nesta edição, ele foi mostrado, na série de matérias que abordam a greve, como mediador, pessoa sensata e razoável, que colocava os interesses dos trabalhadores acima de tudo, mesmo tendo optado por uma trégua na greve. O mérito da organização sindical e de suas respectivas conquistas era todo seu.

Uma imagem como esta pode ser considerada um elogio da revista ao sindicalista. Qualquer vitória, mesmo isolada, contra os militares, significava uma conquista da sociedade que era, majoritariamente, contrária ao regime. Veja parecia querer enaltecer sua conquista.

Lula também foi destaque internacional. A revista norte-americana Newsweek publicou uma matéria com o título $O$ herói da classe trabalhadora. Ele mal era reconhecido como líder nacional e já estava na mídia internacional. No Brasil, nenhuma publicação havia dado 
tanto crédito à sua conquista. Veja, no entanto, ao fazer referência ao destaque internacional do metalúrgico, prestigiou seu esforço a favor da classe trabalhadora.

O líder sindical foi apresentado, em seguidas imagens da revista, como um negociador, que se encontra com seus opositores, em nome dos trabalhadores, e se esforça para solucionar os conflitos. $\mathrm{O}$ alcance de suas ações fez com que ele se transportasse das rodas de sindicalistas para as de negociações com os patrões, em que teria que se apresentar corretamente e impor suas reivindicações. Em razão dos resultados obtidos, adquiriu ainda mais confiança e passou a ser um líder não apenas dos metalúrgicos do $\mathrm{ABC}$, mas de todos os trabalhadores do país. Foi convidado a intermediar negociações do sindicato da construção civil em Minas Gerais e dos bancários no Rio Grande do Sul. De acordo com a revista: "Lula parece ter demonstrado que no Brasil, mesmo não havendo um comando nacional de trabalhadores, há uma pessoa capaz de comandar os trabalhadores."

Provavelmente, em 1979, a Veja ainda não dispunha de muitas fotografias do então líder sindical Luiz Inácio da Silva, o Lula (o pseudônimo só seria incorporado a seu nome anos mais tarde). A pouca disponibilidade de imagens de arquivo, por um lado, praticamente obrigava a revista a publicar as que estivessem disponíveis - cobertura de eventos em que o sindicalista estivesse envolvido, de discursos em portas de fábrica até sua prisão, passando, naturalmente, pelas mesas de negociação - e, por outro lado, dificultava a construção de um discurso fotográfico pró ou contra Lula.

A análise imagética permite considerar que a revista não o preteriu e nem o desvalorizou em suas páginas. Pelo contrário. Como Lula representava mais uma voz - e de peso - que se levantava contra a ditadura militar, luta uníssona da imprensa brasileira à época, a revista tratou de dar-lhe destaque e atribuir-lhe a importância de um líder sindical em luta por melhores condições de trabalho e salário para os seus representados diretos e, indiretamente, para todos os trabalhadores do país. 


\section{9 - Um candidato metalúrgico}

Em 1989, Luiz Inácio era um dos candidatos à Presidência da República. Logo no começo dessa década, deixou o sindicalismo, fundou o PT e a Central Única dos Trabalhadores (CUT) e se tornou um político. Já havia sido deputado federal e membro da Assembléia Constituinte. Seu universo já não era o das fábricas e das convenções sindicais, mas o das reuniões políticas. Ainda assim, seu comportamento pouco mudou.

Apesar de se apresentar em alguns compromissos políticos de forma bem vestida, na maioria das vezes mantinha a simplicidade de um metalúrgico. Em apenas duas das fotos analisadas estava de terno. $\mathrm{O}$ que prevaleceu foram as camisas abertas e para fora da calça, as camisetas, os moletons e as blusas de lã, feitas artesanalmente. A barba e o cabelo continuavam vastos, como dez anos antes. Suas idéias também eram as mesmas - um pouco revolucionárias e talvez utópicas. Muitas delas, referentes à reforma agrária, à distribuição de renda e à dívida externa, por exemplo, assustaram grande parte da população e também o empresariado.

A revista, que lhe deu visibilidade em 1979, agora não fazia questão de enaltecer suas qualidades. A imprensa, de modo geral, que nutriu certa afinidade com a causa de Lula naquela época - pois ambos lutavam contra o regime militar, cada um por seus motivos - não apoiava sua campanha. Veja explicitou em suas páginas a imagem de um suburbano, sem cultura, sem trato, sem postura de presidente. E era, constantemente, comparado a seu adversário, Fernando Collor de Melo, que, como vários estudos mostram, usou de todos os recursos publicitários para destacar uma imagem positiva diante dos eleitores.

Pelas fotos analisadas tem-se a impressão de que não se trata de um candidato com força política suficiente para vencer uma eleição, pois está sempre sozinho; aparece poucas vezes entre a multidão ou em comícios. Como candidato está distante dos sindicalistas dos quais, antes, era líder. Mesmo quando está acompanhado ou rodeado de pessoas, o recorte fotográfico o destaca dos demais, distanciando-o. 
As fotos, pouco criativas nesta fase, talvez traduzissem que a campanha também não andava bem. As imagens horizontais expressavam passividade, uma mesmice, que podiam representar o estado de ânimo da campanha. As mãos no bolso e a falta de atitude do candidato contribuíram. Dessa forma, podiam ser interpretadas pelo leitor como falta de articulação política e até inexperiência.

Mesmo em fotos em que o candidato aparecia em plena campanha não era essa a conotação dada pela revista, como na do ato de tomar um cafezinho, provavelmente após um comício ou passeata. Da forma como foi colocada, desviava a atenção deste fato. Os semblantes pouco risonhos, fruto de cansaço ou preocupação, completaram a cena para que a leitura da imagem fosse, talvez, diferente da realidade.

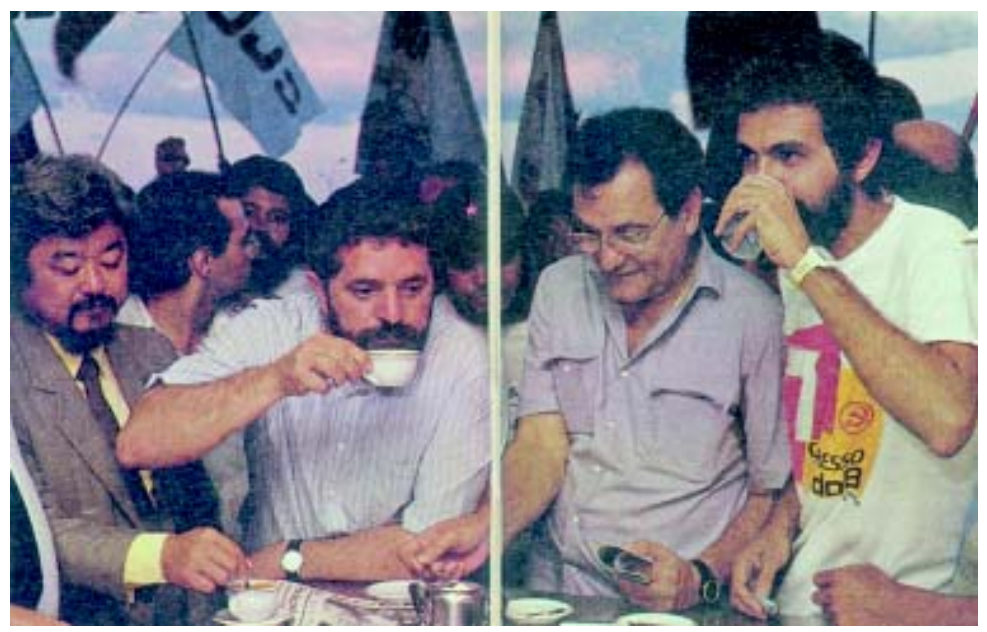

Foto: Orlando Brito - Revista Veja, ano 22, n.32,

16 de agosto de 1989, p.42-43

O fotógrafo utilizou-se da iluminação para concentrar a atenção em Lula e em sua equipe tomando café. O corte americano, que fechou aimagem entre suas cabeças e as cinturas, não permitiu ao leitor se ater muito às bandeiras que, ao fundo, balançavam.

Pela diagramação, textos e fotos, quando a revista trazia matérias de Lula e de seu principal adversário, Fernando Collor de Melo, dava 
predileção a este. As respostas de Collor para as perguntas eram mais firmes e consistentes; as de Lula, mais inseguras e titubeantes. As imagens eram parecidas, mas a de Collor tinha uma pequena vantagem por estar à esquerda e ser assim privilegiada devido ao modo de leitura ocidental.

Nesta época, Lula não se preocupava com aparência; muito pelo contrário, orgulhava-se de ter sido pobre. E não se intimidava por não saber inglês, ou ser menos instruído que os outros. "Por que eu tenho que mudar minha vida se for eleito presidente da República?", perguntava. “O meu povo quer que eu seja o que eu sou, ée isso o que eu tenho que ser", respondia.

De acordo com Duda Mendonça (2001) - considerado um dos maiores publicitários do país - faltou assessoria a Lula nesta campanha. Não só com relação à imagem, mas em como se comportar aos ataques proferidos por seus adversários. Cita que não deveria ter retrucado, por exemplo, o ataque de Fernando Collor quando este sugeriu que Lula havia pedido para uma ex-namorada abortar. Segundo Mendonça:

O que Lula não poderia jamais ter feito foi desperdiçar aqueles preciosos minutos para dizer que, em vez de caçador de marajás, Collor era um caçador de maracujás. [...] Mas se, em vez disso, tivéssemos visto, naquela noite, um Lula emocionado, falando com a alma e com o coração, como já o vimos em alguns momentos, a conversa talvez tivesse sido outra. (MENDONÇA, 2001, p.62).

Em 1989, com o uso do ângulo de mergulho - que desvaloriza a pessoa fotografada - e a edição de fotografias em que o candidato aparecia sozinho, pouco destacado em pequenos grupos de pessoas ou desvalorizado, quando fotografado nos comícios de seu partido, a revista intrinsecamente assumia que preteria Lula em detrimento de seus adversários, especialmente Fernando Collor de Melo, que havia surgido e se consolidado como a alternativa mais viável para a resolução dos problemas econômicos brasileiros, principalmente depois que o então presidente da FIESP - Federação das Indústrias do Estado de São Paulo, Mário Amato, declarou que se Lula vencesse a eleição "300.000 empresários deixariam o país". 


\section{4 - Lula contra o Real}

Já em 1994, percebe-se algum cuidado do candidato com seu visual. Em alguns comícios ousou usar paletós e a frequiência com que foi fotografado de terno aumentou. Contudo, ainda prevaleciam roupas mais "confortáveis", entre elas a camiseta e o jeans.

No começo do ano, Veja acompanhou algumas de suas jornadas com as Caravanas da Cidadania, peregrinação feita em cidades do interior do país, dando palestras e colhendo idéias. Depois do lançamento oficial da campanha, predominaram as fotografias em que Lula se encontrava com autoridades, participava de encontros do partido, reuniões eleitorais, etc. Há também fotografias de seus comícios. No entanto, nesses casos, a revista optou por fotografias tiradas na direção do público para o palanque e, com esse artifício, os eleitores apareciam sempre achatados e de costas. Assim, ficava difícil para o leitor ter uma noção exata da popularidade de Lula no decorrer da campanha. A revista ocupou-se, em grande parte de suas matérias, em repercutir as suspeitas de corrupção que envolviam seu candidato a vice, seus amigos e até ele mesmo.

Em uma das matérias, há uma crítica a seus discursos durante os comícios. De acordo com a Veja, o petista usa a técnica do catastrofismo - quanto pior estiver a situação social do país, melhor será para ele. Diz-se que ele repete as histórias e, em cada local, aumenta um pouco a tragédia. A imagem escolhida contribuiu para enfatizar e consolidar essa idéia. Lula está de frente para a multidão em cima do que parece um palanque, pelo que o plano médio desta foto permite inferir. Na vertical, permite observálo de corpo inteiro e, ainda, a multidão de costas, em primeiro plano e sem foco, e sua equipe ao fundo. Nessa fotografia, percebe-se um pouco de desatenção e desmotivação da multidão, que pouco se mobiliza e nem agita bandeiras. Apesar do desfoque do primeiro plano, vê-se um rosto virado para o lado, de quem não se atém às palavras do candidato em campanha. No palanque, poucos de sua equipe estão voltados para ele. O que se observa é muita conversa paralela. De acordo com o contexto da revista, provavelmente já estivessem cansados de ouvir a mesma história. 


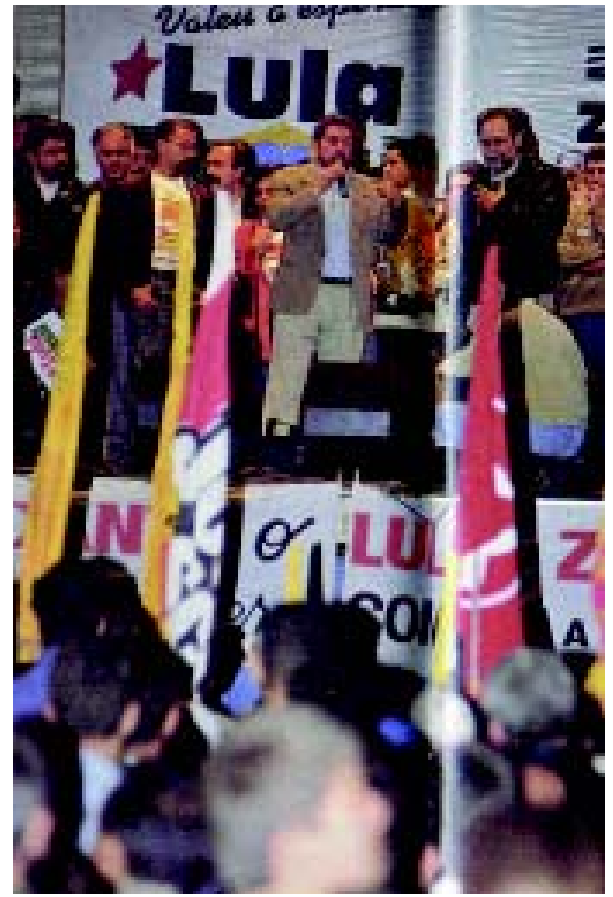

Foto: Antonio Milena - Revista Veja,

10 de agosto de 1994, p.36-37

A composição pouco equilibrada e a exagerada quantidade de elementos na fotografia dificultam a identificação de Lula, de modo que a atenção do observador se dispersa e não se prende à figura do candidato. Com isso, a revista acentua sua incapacidade de mobilização nesse momento da campanha. Nem é preciso ser conhecedor da linguagem fotográfica para perceber isso e, assim, a revista consegue passar sua mensagem de desmobilização que, aliada à legenda: $O$ candidato no palanque: criando... fábulas, certamente produz o efeito desejado até mesmo no leitor menos atento. Essa estratégia, comum nos jornais e revistas, há muito foi denunciada Gisèle Freund (1995): “A objetividade da imagem é apenas uma ilusão, e as legendas que a comentam podem alterar totalmente a sua significação." 
Produz-se a sensação de distanciamento cada vez maior do candidato, traduzindo-se em poucas perspectivas de vitória nas eleições.

A análise que este artigo fez da imagem de Lula, durante esse ano eleitoral, revela uma grande dicotomia existente antes e depois do lançamento do Plano Real. Antes, era saudado, estava em primeiro lugar nas pesquisas de intenção de votos e colhia bons frutos das Caravanas da Cidadania. Depois, vê-se Lula mais contido, percebendo escapar, mais uma vez, a vitória; vencido por um plano econômico e por um sonho de mudança.

O candidato continuou adotando a barba que o identificou em 1979 como presidente do sindicato dos metalúrgicos. Contudo, ela não era mais tão vasta; na televisão e em fotografias a barba contribuía para denegrir a imagem do candidato, passava a sensação de falta de higiene. $O$ aparecimento dos primeiros fios brancos revela a distância cada vez maior daquela época em que suas idéias eram seguidas por multidões.

Foi a partir de julho que a situação eleitoral, antes favorável a Lula, começou a se modificar. Já no terceiro dia do Plano Real, diminuiu a diferença entre ele e Fernando Henrique Cardoso, que se tornou seu principal rival. Sua expressão começou a mudar: a segurança foi dando lugar à incerteza e ele se sentiu ameaçado, pela primeira vez. Todas as atenções centraram-se, então, no "pai" do novo plano econômico.

De início, o candidato petista teve uma reação negativa ao Plano Real. Pensava ser um plano com fins meramente eleitoreiros. Dimenstein e Souza, no livro A história real - trama de uma sucessão (1994), sustentam que o plano, num primeiro momento, tinha mesmo essa finalidade. Mas ele havia sido criado para surtir efeitos positivos e melhorar a condição econômica do país. Lula ainda não tinha essa visão e pensava que seria mais um plano passageiro, como outros anteriores. Com o passar do tempo, percebeu que a população nutria esperanças com relação ao plano e que, se o atacasse, diminuiria suas chances de vencer as eleições.

Nesta imagem apresentada pela revista, Lula ainda não tinha consciência de que atacar o plano econômico seria um erro. O candidato fez críticas ao mostrar uma nota de um real presa às pontas dos dedos. A 


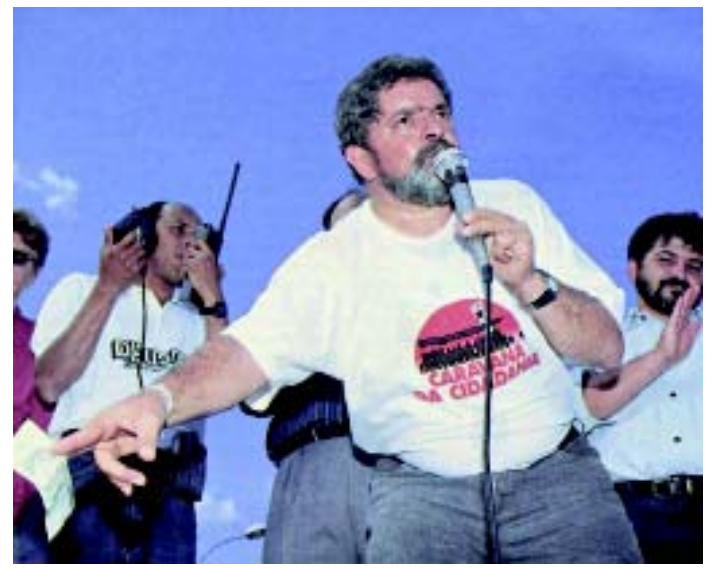

Foto: Antonio Milena - Revista Veja,

28 de setembro de 1994, p.33

partir do candidato, que está ao centro da imagem, o leitor é convidado a percorrer o caminho de seu braço, que leva à nota. Essa pequena perspectiva formada faz com que dificilmente um leitor passe os olhos pela fotografia sem notar o dinheiro em sua mão.

O plano médio, que conceituamente interage o sujeito ao ambiente, permite atentar à presença de pessoas da equipe de Lula ao fundo, que lhe dão apoio técnico e moral, engrossando o coro das palmas.

Sua expressão facial fechada mostra seu descontentamento com o plano que, segundo ele, foi criado para derrubá-lo. A foto é, como um todo, um retrato da mudança de humor do candidato e, inclusive, revela seu principal motivo: o Plano Real. Essa não foi uma imagem favorável a Lula. Ela conota que ele estava contra o Real, ou seja, não seria ele o candidato daqueles que nutriam esperanças de que o novo plano econômico pudesse trazer benesses.

Em agosto, FHC já tinha uma vantagem consolidada sobre Lula e, inclusive, ameaçava vencer ainda no primeiro turno. As fotografias na revista, a partir deste momento, denunciavam o abatimento do candidato petista.

A falta de liberdade dos profissionais de marketing que conduziam a campanha de Lula foi considerada um dos principais motivos do fracasso da campanha em geral: 
Nos primeiros dias de agosto, com a queda de Lula nas pesquisas, a cara da campanha é um pouco a cara de seu mentor, seja nas ruas ou na TV: circunspecta, sombria, nada amigável. Alegria, nem pensar. Se em 1989, a imagem de Lula esteve associada ao sonho e à esperança, agora está atrelada à agressividade e ao mau humor. (MEDEIROS, 1994, p.73-74).

Mas a parcialidade da mídia, pendendo em peso para a campanha de FHC, foi a principal alegação dos petistas para a derrota de Lula:

Toda a imprensa apoiou o Fernando Henrique. Brizola tem razão, a mídia é um partido único. Além do apoio dela e dos empresários, o cara tem ainda a máquina do governo trabalhando para ele e ainda apela para o jogo sujo. [...] Ele nem precisa fazer comício. (KOTSCHO apud MEDEIROS, 1994, p.187-188).

\section{8 - A campanha mais difícil}

Em 1998, Lula começou a apresentar os primeiros sinais da idade. Apesar de ainda jovem, pode-se notar que sua barba e cabelos não mais conservavam o negro de antigamente. Estavam, agora, mesclados por muitos fios brancos, dando o aspecto grisalho. Outra observação que salta aos olhos é que se tornaram raras as fotografias em que ele não está de terno. Esta vestimenta, que antes não fazia parte de seu guarda-roupa, tornou-se usual. Até mesmo em uma matéria em que o candidato "batia uma bolinha" em um campo de futebol, aludindo à Copa do Mundo, estava de terno.

O fato de ter se deixado fotografar em um campo, brincando com a bola, fez parte de uma prática que ficou evidente neste ano eleitoral. Lula procurava se aproximar mais do eleitor, fazendo com que ele se identificasse com o candidato e se sentisse valorizado. Em razão desta tática de aproximação, o candidato acompanhou o desfile das escolas de samba no Rio de Janeiro, afinal o carnaval é a maior festa popular do país. Alertado de que os gaúchos são muito tradicionalistas, fez questão de 
usar roupas típicas regionais quando de seus comícios no Rio Grande do Sul. E, claro, aproveitou a realização da Copa do Mundo de Futebol para aumentar sua popularidade entre os adeptos do esporte.

O uso da tecnologia também foi marcante na campanha de 1998. Ainda em janeiro, a revista Veja publicou uma foto de Lula dentro de um avião particular, trabalhando em um lap-top.

As mudanças visuais e estratégicas percebidas na campanha deste ano se deram em razão de sua assessoria de marketing. Para esta reportagem, Lula foi fotografado ao lado do chefe dos publicitários de sua campanha, Toni Cotrim. Sua campanha não andava bem. Em matéria anterior, a revista explicava que o índice de aprovação de seu programa televisivo tinha ficado abaixo da média dos demais e que havia frustrado as expectativas dos eleitores. O momento, portanto, exigia mudanças.

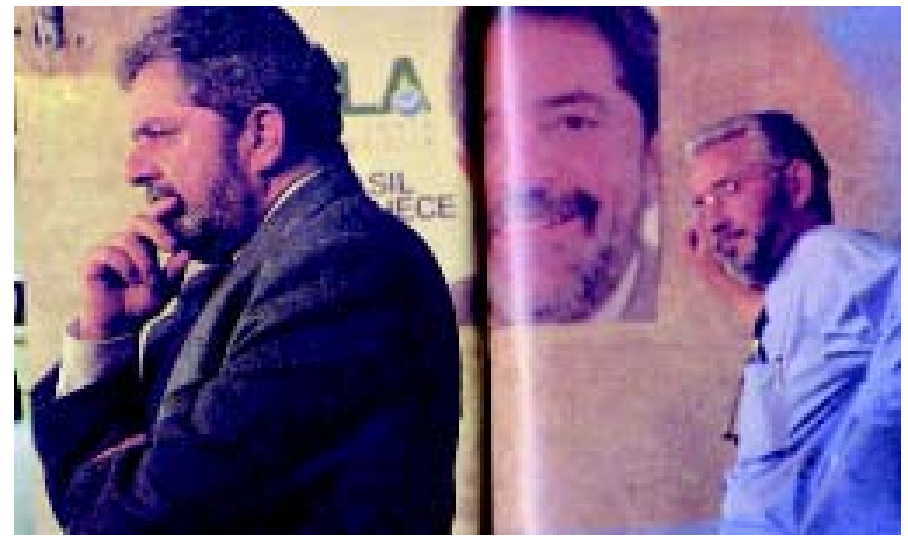

Foto: Egberto Nogueira - Revista Veja, ano 31, n.37, 16 de setembro de 1998, p.44-45

A tensão no rosto de Lula se contrapõe, fortemente, com a expressão do candidato no cartaz da campanha, fixado na parede, ao fundo. Os braços cruzados, a mão levada à boca, olhar ao horizonte, são manifestações de quem busca solução para conflitos, novas idéias para alavancar a campanha na reta final. O publicitário (à direita) parece 
impaciente: encosta-se na parede, apoiado em uma das mãos e, com a outra na cintura, com as mangas das camisas dobradas e olhar cabisbaixo, parece esperar uma decisão do candidato.

Na campanha de 1998, consolidou-se a imagem de um Lula com visões políticas diferentes daquelas que o lançaram na década de 80 . Iniciaram-se as articulações com empresários e demais políticos com vertentes ideológicas diversas. Depois de tantas tentativas frustradas como candidato, percebeu a necessidade de se aliar para obter êxito. Entretanto, o PT ainda não compartilhava da mesma opinião e criava resistência.

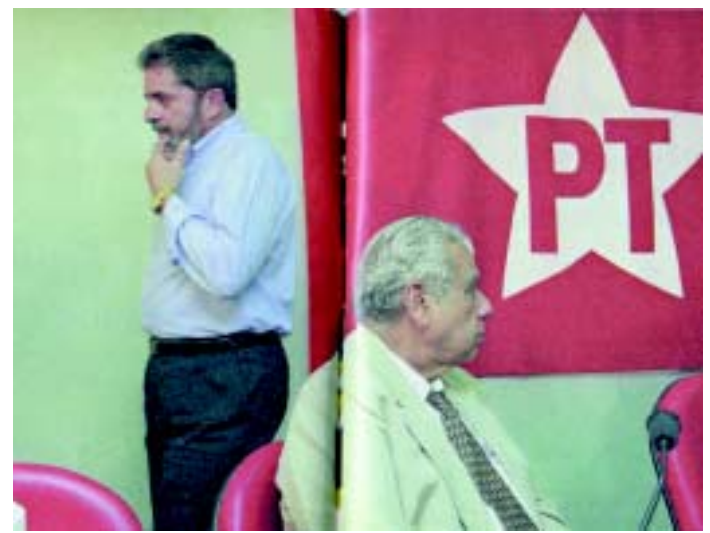

Foto: Sérgio Andrade - Revista Veja, ano 31, n.11, 18 de março de 1998, p.28-29

Em seminário organizado pelo Instituto Cidadania, presidido por Lula, os militantes se assustaram com os nomes dos debatedores, principalmente com a presença de Antônio Ermírio de Moraes. A fotografia que ilustra a matéria mostra Lula com Antonio Ermírio em uma mesa de reuniões do que parecia ser o seminário. Nenhum dos dois tem a expressão de estar feliz ou satisfeito. No plano médio em que os dois foram fotografados, estão de costas um para o outro e com expressões nítidas de preocupação. Lula, em pé, atrás das cadeiras, parece andar de um lado a outro e mexe no queixo como sinal de tensão. O empresário, por sua vez, parece esperar que alguém se aproxime. Pela matéria, não se tem 
certeza se houve ou não o seminário, mas a ausência de mais pessoas na foto passa a impressão de poucas presenças. As roupas elegantes que vestem explicitam o caráter formal da reunião e possivelmente necessário para o apoio do grupo Votorantim, o qual Antônio Ermírio de Moraes representava.

Colocados ao centro da imagem, provocam um certo desequilíbrio imagético na composição, talvez até proposital. Numa das laterais da fotografia aparece a bandeira do PT. Na outra uma parede vazia. O desequilíbrio permite pensar que esse vazio pode representar a falta de algum elemento à reunião, talvez o apoio do próprio partido. Lula enxergava nas possíveis alianças chances reais de vitória, mas era preciso o apoio e a concordância do partido para as alianças que o candidato pretendia.

Não se pode considerar que a revista tenha utilizado as fotografias publicadas para diminuir a importância de Lula em relação aos demais candidatos ou denegrir sua imagem. As fotos, em geral, eram plasticamente bonitas, muito coloridas, com planos, efeitos e ângulos variados, mostrando as mudanças positivas do candidato. $\mathrm{O}$ fato é que seu adversário, Fernando Henrique Cardoso, tinha grande aceitação popular e empresarial devido aos efeitos do Plano Real e, por isso, venceu as eleições. Alguns estudiosos dizem que o fato de ser candidato à reeleição, com propostas claras de dar continuidade ao trabalho que havia desenvolvido em seu primeiro mandato, contribuiu - e muito - para sua vitória.

[...] que a experiência de 98 sirva para uma reflexão sobre a instituição reeleição, pelo que implica em desigualdade de condições entre o candidato ao segundo mandato e seus oponentes, sobretudo se agravada pela possibilidade do não afastamento do cargo, como permite a atual legislação e usufruiu Fernando Henrique. (VENTURI apud RUBIM, 2000, p.117).

Jornalistas e comentaristas políticos apontam a derrota de Lula em razão de sua imagem haver sofrido um desgaste natural por sucessivas derrotas: 
A imagem de Lula ficou muito danificada pelas sucessivas derrotas e sistemáticas campanhas de difamação e desqualificação pela mídia. A campanha não conseguiu reconstruir essa imagem. (KUCINSKI, 2000, p.143).

A análise imagética da eleição de 1998 não é desfavorável a Lula. Um análise criteriosa no conjunto das fotografias publicadas conota que o candidato não foi, em termos de imagem, prejudicado pela revista. Nas fotografias, o petista apareceu melhor que nos anos anteriores. Mas, mais que o tratamento imagético, foi o candidato que mudou. A idade e as lições das duas eleições anteriores o haviam amadurecido politicamente. Além disso, as alianças que costurava com empresários contribuíram para sua mais ampla aceitação. Os motivos que deflagraram sua derrota, conforme apontaram Kucinski e Venturi, respectivamente, foram suas sucessivas derrotas anteriores e a vantagem de Fernando Henrique Cardoso concorrer à reeleição, com a benção do sucesso do Plano Real.

\section{2 - O ano da vitória}

No início de 2002, o grande destaque da Veja foi a candidata Roseana Sarney. A novidade de ter uma mulher pela primeira vez concorrendo à Presidência da República caiu nas graças da revista, que a valorizou em relação aos demais. Mas, tão logo Roseana abandonou sua candidatura, Lula ascendeu em seu lugar. Com ternos modernos e assinados por estilistas famosos, aparência modificada depois de um tratamento dentário, cortes de cabelo que favoreceram o penteado, propostas que pareciam bem razoáveis para a realidade do país (e bem diferentes daquelas de 1989), ele parecia reunir as qualidades exigidas de um presidente. E assim a revista o tratou. Ressaltou sua capacidade de construir alianças, ao mostrá-lo ao lado de Fernando Henrique, José Alencar, fazendeiros, bancários e industriais (que em 1989 ameaçaram 
deixar o país caso ele vencesse), José Sarney e até mesmo o presidente norte-americano George W. Bush.

A maneira do Lula se vestir mudou muito, antes eram os ternos simples de R \$250,00 e hoje ternos Giorgio Armani de R \$ 4.000,00. O sorriso do Lula também mudou bastante, graças a um tratamento dentário aos domingos. Corte de cabelo e barba hoje são feitos por profissionais e não mais por um de seus amigos dos tempos de movimento sindical. A Campanha não foca mais nas prisões de candidatos do PT na época das Diretas (como aconteceu em todas as campanhas do Lula até hoje), já que o brasileiro não acha bonito o fato de alguém ter sido preso, e na verdade até desconfia disso. A forma como o Lula fala também mudou. Alguém ouviu ultimamente expressões fáceis do Lula como "Vamos à luta companheiro!'”? Não, não ouviram justamente porque a luta do Lula não era bem interpretada por despolitizados e por pessoas mais moderadas que associavam essa luta com baderna e bagunça, e isso causa certo temor na cabeça dos eleitores. A campanha renega totalmente às idéias do PT e foca totalmente no ser humano Lula, em sua família e sua história. Ele chega até a chorar durante a propaganda. Nas propagandas, repetir a gravação até achar a melhor iluminação, a melhor imagem, tudo em busca da perfeição, da assepsia total. (MENDONÇA, 2001).

Lula aparentava assim que tinha capacidade para governar e o faria de forma democrática, defendendo os trabalhadores, que sempre foram alvo de suas principais propostas, mas se atendo também às necessidades e exigências de investidores, empresários, produtores, industriais e outros segmentos organizados da sociedade.

Atendendo a conselhos de sua assessoria, não se deixou envolver em ataques dos adversários e, com isso, não criou polêmicas que arranhassem sua imagem. Foi a fase que o próprio candidato denominou e a imprensa adotou de "Lulinha - paz e amor". Em razão dessa estratégia de marketing, era flagrado sempre sorrindo, de bom humor, otimista, cercado de crianças ou fazendo orações.

A assessoria publicitária, de acordo com alguns estudiosos, foi fundamental para a vitória de Lula. Feita por Duda Mendonça 
- considerado um dos melhores publicitários do país - deu ao candidato petista todo o suporte necessário aos programas de televisão e rádio, as dicas sobre sua imagem, consistência para seus pronunciamentos e para os debates, orientações para sua postura de serenidade para não se deixar envolver em intrigas, etc.

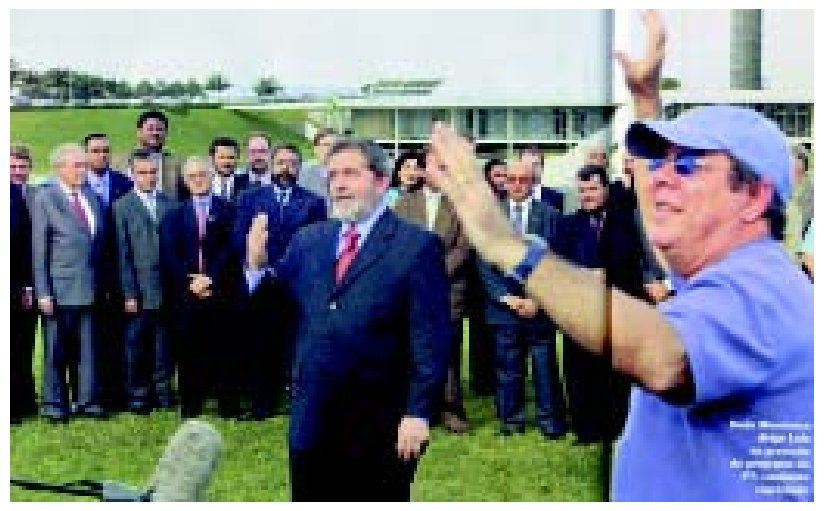

Foto: Alan Marques - Revista Veja, ano 35, n.19, 22 de maio de 2002, p.48-49

A campanha procurou ressaltar o que o PT mostrou de melhor em quinze anos de política. Mostrou que as novas propostas do partido refletiam o desejo de toda a sociedade e, assim, de acordo com Duda Mendonça, essas propostas foram se revertendo em votos:

$\mathrm{Na}$ cabeça dessas pessoas, cansadas e decepcionadas com tanta injustiça e miséria, o PT começa a significar mais e mais, a esperança de um Brasil diferente - mais humano, menos frio. A frase "o PT merece uma chance, uma oportunidade" era cada vez mais ouvida. $\mathrm{Na}$ verdade, essas pessoas ainda não estavam inteiramente convencidas a votar no PT. Mas, com certeza, já foram tocadas pela pontinha da estrela. (MENDONÇA, 2001, p.262).

E foi assim que Lula tornou-se, em 2002, o presidente do Brasil. A fotografia da vitória é um reflexo de tudo o que foi construído durante a campanha por ele e sua equipe. Sua composição estética reflete a presença de uma equipe de comunicação preocupada em consolidar em Lula a 
imagem do que a população espera de um presidente, um homem de postura e posicionamento, com capacidade administrativa, bem sucedido pessoal e profissionalmente, com liderança, carisma e simpatia. Sua expressão contente revela a mudança interior de um homem que nasceu pobre, sem perspectivas de vida, como muitos brasileiros; mas que com garra, perseverança e inteligência conseguiu alcançar uma posição de destaque e de importância internacional.

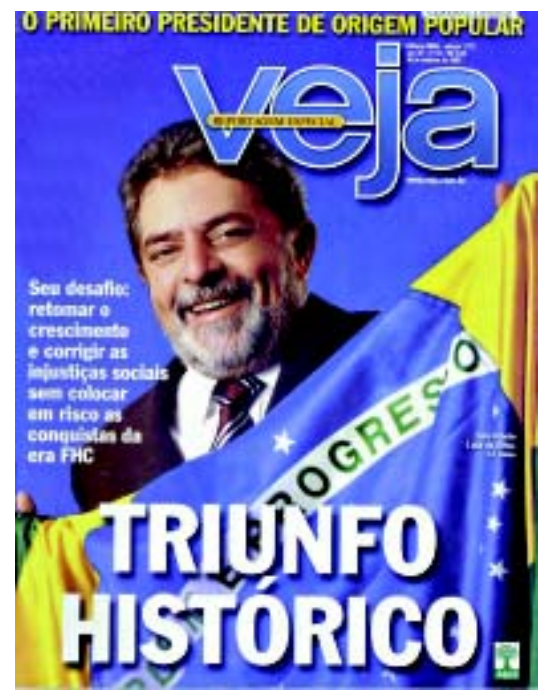

Foto: Revista Veja, ano 35, n. 43, 30 de outubro de 2002, capa

[...] persona de Lula [...] hoje, retrata, ao mesmo tempo, o sindicalismo do ABC, a administração das prefeituras em tantas cidades-chave do país e o reencontro do interior e do Brasil de fundo - o país que é da fome, até certo ponto, e não o do imaginário da campanha de segurança alimentar; que é do desemprego, até certo ponto; que é, sobretudo, o da ruptura dos serviços sociais do Estado, e não da mera ruína do assistencialismo populista pré64, do peleguismo varguista. (CANDIDO, 2002, p.227).

"Ordem e Progresso", as palavras da bandeira nacional, em tese resumem os desejos de toda a nação para seu país. Para Lula tem outro significado. Durante anos ele repetiu insistentemente que queria uma 
política que privilegiasse os pobres, fizesse uma justa distribuição de renda, desse oportunidade para todos, fornecesse saúde e educação de qualidade, trabalho com justa remuneração. Seus ideais parecem não haver mudado, mas a forma como ele pretende alcançar isso tudo mudou.

As estrelas representam os Estados brasileiros e o Distrito Federal, mas é também o símbolo do Partido dos Trabalhadores, do qual ele é um dos fundadores e, agora seu maior expoente. A chegada da estrela ao poder máximo da nação foi temida durante anos por grande parcela da população, mas, na última eleição presidencial, tornou-se a esperança de um Brasil melhor.

\section{Considerações finais}

A mudança na imagem de Lula, tornando-o mais imponente e com ar de experiente, proporcionou-lhe conquistar uma fatia do eleitorado que antes pouco votava nele: a classe baixa. A partir de sua eleição, tornou-se uma esperança para ela, que nele depositou sua confiança.

De certa forma, Veja mudou o tratamento dispensado a Lula; é inegável que sua imagem em 2002 era mais favorável do que em 1989. Suas fotografias passaram a ocupar espaços maiores e de destaque dentro das páginas da revista. As edições fotográficas o favoreceram na escolha de imagens agradáveis e visualmente bonitas. Mas houve também a mudança pessoal do candidato. Apoiado por uma eficiente equipe de marketing, ele modificou hábitos para se adequar à imagem imponente de um presidente e transformou sua história de lutas sindicais e políticas em conhecimentos necessários para governar um país.

Não se pode afirmar, contudo, que esses fatores o tenham levado à Presidência. Seriam necessárias várias pesquisas para descobrir quais os motivos que levaram a população a escolhê-lo. Se se considerar, entretanto, que a revista é uma formadora de opinião e que influencia na escolha das pessoas, talvez se possa dizer que ela tenha sido uma das responsáveis por esta eleição. 


\section{Referências}

BONI, Paulo César. O discurso fotográfico: a intencionalidade de comunicação no fotojornalismo. Tese (Doutorado em Ciências da Comunicação) - ECA/USP, 2000.

CANDIDO, Mendes. Lula: a opção mais que o voto. Rio de Janeiro: Garamond, 2002.

DIMENSTEIN, Gilberto; SOUZA, Josias de. A história real: trama de uma sucessão. São Paulo: Ática, 1994.

FELDMAN-BIANCO, Bela; LEITE, Miriam L. Moreira (Org.). Desafios da imagem: fotografia, iconografia e vídeo nas ciências sociais. Campinas: Papirus, 1998.

FREUND, Gisèle. Fotografia e sociedade. Tradução por Pedro Miguel Frade. 2 ed. Lisboa: Vega, 1995.

JOLY, Martine. Introdução à análise da imagem. Campinas:

Papirus, 1996.

KUCINSKI, Bernando. Síndrome da antena parabólica. São Paulo: Fundação Perseu Abramo, 1998.

LIMA, Venício A. Mídia, teoria e política. São Paulo: Fundação Perseu Abramo, 2001.

MENDONÇA, Duda. Casos e coisas. São Paulo: Globo, 2001.

MOREL, Mário. Lula, o metalúrgico: anatomia de uma liderança. Rio de Janeiro: Nova Fronteira, 1981. 
NÊUMANNE, José. Atrás do palanque: bastidores da eleição 1989.

3. ed. São Paulo: Siciliano, 1989.

PARANÁ, Denise. Lula, o filho do Brasil. São Paulo:

Fundação Perseu Abramo, 2002.

PATARRA, Ivo. Lula, presidente do Brasil: a estratégia que derrotou FHC em 1994. São Paulo: Alfa-Omega, 1995.

POMAR, Wladimir. Quase lá: Lula o susto das elites. São Paulo: Brasil Urgente, 1990.

POYARES, Walter. Imagem pública: glória para uns, ruína para outros. São Paulo: Globo, 1998.

RUBIM, Antonio Albino C. (Org.). Mídia e eleições de 98. Salvador: Facom/UFBA, 2000.

SILVA, Luiz Inácio da. Lula sem censura. Petrópolis: Vozes, 1981.

TAVARES, Olga Maria. Fernando Collor: o discurso visual, ascensão \& queda.Tese (Doutorado em Comunicação \& Semiótica) - PUC/SP, 1999. 